\title{
Hydroxystilbamidine Isethionate
}

National Cancer Institute

\section{Source}

National Cancer Institute. Hydroxystilbamidine Isethionate. NCI Thesaurus. Code C65871.

The isethionate salt form of hydroxystilbamidine, a cationic dye with antifungal, antitrypanosomal, antimalarial, and carcinostatic activities. Hydroxystilbamidine is able to bind to DNA and RNA in a non-intercalating manner, and is a powerful inhibitor of ribonucleases, thereby impeding cellular processes in protozoa. This agent was also shown to bind to lysosomes and induced a large number of lysosome-like bodies and secretion granules in trypanosome. 